\title{
Day Times Millimole per Milliliter
}

National Cancer Institute

\section{Source}

National Cancer Institute. Day Times Millimole per Milliliter. NCI Thesaurus. Code C85589.

Days times millimoles per milliliter. 